\title{
Constraints Faced by Co-Operative Dairy Farmers in Adoption of Recommended Dairy Management Practices
}

\author{
G.J. Panchbhai ${ }^{1}$, M.F. Siddiqui ${ }^{2}$, M.N. Sawant ${ }^{3}$, A.P. Verma ${ }^{4}$ and J. Parmeswaranaik ${ }^{4}$ \\ ${ }^{1}$ Department of Livestock Production and Management, Post Graduate Institute of Veterinary \\ and Animal Sciences (MAFSU), Akola-444104, India \\ ${ }^{2}$ Department of Livestock Production and Management, College of Veterinary and Animal \\ Sciences (MAFSU), Parbhani-431402, India \\ ${ }^{3}$ Department of Veterinary and Animal Husbandry Extension, Bombay Veterinary College, \\ (MAFSU) Parel, Mumbai -12, India \\ ${ }^{4}$ Dairy Extension Division, National Dairy Research Institute, Karnal-132001, Haryana, India \\ *Corresponding author
}

\section{A B S T R A C T}

Keywords

Constraints, Cooperative, Dairy, Management.

Article Info

Accepted:

24 February 2017

Available Online:

10 March 2017
India is a major leader in milk production but its potential is not fully explored to the extent. Several constraints are perceived and faced by dairy farmers during adoption of recommended dairy management practices. The aim of this study was to evaluate constraints faced by dairy farmers in co-operative. Present study was undertaken in Shivamrut Dudh Utpadak Sahakari Sangh Maryadit, Akluj dist. Solapur of Maharashtra. The data were collected from 200 dairy farmers randomly selected from 10 villages through interview schedule, analyzed and results were interpreted. Major constraints recorded were ticks and other ectoparasites present in animal shed, milk production of local breeds is very low, dairy animals require large quantity of feed, higher cost of concentrate and cross bred animals are more prone to diseases,. All these constraints may lay significant impact on milk production in terms of quality and quantity. For overall development of dairy sector in this area dissemination of knowledge, transfer of technology and role of dairy cooperatives would be crucial.

\section{Introduction}

Now a day's Indian dairy industry is at cross roads. As per economic survey 2015-16, India ranks first in milk production, accounting for 18.5 per cent of world production, achieving an annual output of 146.3 million tonnes during 2014-15 as compared to 137.69 million tonnes during 2013-14 recording a growth of 6.26 per cent. Whereas, the Food and Agriculture Organization (FAO) has reported a 3.1 percent increase in world milk production from 765 million tonnes in 2013 to 789 million tones in 2014. The success of the dairy industry has resulted from the integrated co-operative system of milk collection, transportation, processing and distribution, conversion of the same to milk powder and products, to minimize seasonal impact on suppliers and buyers, retail distribution of milk and milk products, sharing of profits with the farmer, which are ploughed back to 
enhance productivity and needs to be emulated by other farm produce/producers. The cooperative dairy enterprises also proved its role in changing the socio-economic status of the farmers and also provided the dependable source of income for the poor farmers in villages. The major reasons for the dismal scenario are poor product quality and price competitiveness. Under WTO regime, in order to meet the international standards quality in terms of safety and wholesomeness is crucial. There is need to maintain quality of milk during entire production chain. To achieve this, bridging of gaps between dairy innovations and its adoption by dairy farmers is need of hour. The adoption rate of such technologies varies from place to place and region to region which chiefly depends upon the socioeconomic status of the community and community participation. These are the constraints which mimic development. Many constraints exist simultaneously in several stages of milk production under field conditions. Constraints are nothing but the problems that come in the way of adoption of technology. If these constraints are identified, they are helpful to bridge the gap between dairy technology and its adoption by dairy farmers (Rathod et al., 2014). In Maharashtra state milk production and network of dairy cooperatives is well established and concentrated in western part. Therefore, the present study was undertaken with the objective to study various constraints perceived by dairy farmers in adoption of recommended dairy management practices.

\section{Materials and Methods}

Solapur district was selected purposively for the present study as district is having no of co-operatives. Dairy co-operative entitled "Shivamrut Dudh Utpadak Sahakari Sangh Maryadit, Akluj” was purposively selected as dairy co-operative is having a good network among dairy farmers. Ten villages were selected from the jurisdiction of cooperative society on the basis of random sampling from irrigated part, partially irrigated and dry part of the area to have composite sample for study. Twenty member producers of dairy cooperative society were selected randomly from each village. Thus in all 200 respondents from 10 villages were selected as sample for the investigation. The ex-post facto research design was followed. An interview schedule was developed in accordance with objectives of the study and it was pre tested and translated in to Marathi. The Statistical measures such as percentage and rank method were used.

\section{Results and Discussion}

The constraints have been divided into seven major categories and the responses of dairy farmers were expressed as frequency and percentage.

\section{Reproduction}

Among the reproduction related constraints, the majority of the respondents i.e. $67 \%$ reported long calving interval followed by 38 $\%$ of the respondents faced constraint of poor conception rate of AI, whereas 7.5, 2.5 and $1.5 \%$ of the respondents faced constraints of unable to detect heat in dairy animals, nonavailability of developed breeds dairy animals in local market and non-availability of breeding bull of pure breed, respectively (Table 1).

\section{Feeding}

The majority of the respondents (89\%) faced constraint of more amount of feed required to feed dairy animals followed by $87 \%$ of the respondents reported higher prices of concentrates, whereas 31 and $21 \%$ of the respondents reported non-availability of the green fodder round the year and unavailability of land for fodder crops, respectively. 
Table.1 Constraints faced by dairy farmers while adoption of recommended dairy management practices

\begin{tabular}{|c|c|c|c|}
\hline Sr. No. & Constraints & Frequency & Percentage \\
\hline A. & Reproduction & & \\
\hline 1. & Long calving interval & 134 & 67.00 \\
\hline 2. & Poor conception rate of AI & 76 & 38.00 \\
\hline 3. & Unable to detect heat & 15 & 7.50 \\
\hline 4. & Non-availability of breeding bull of pure breed & 03 & 1.50 \\
\hline 5. & Non-availability of developed breeds in local market & 05 & 2.50 \\
\hline B. & Feeds and feeding & & \\
\hline 1. & Dairy animals require large quantity of feed & 178 & 89.00 \\
\hline 2. & Higher cost of Concentrate & 174 & 87.00 \\
\hline 3. & Deficiency of green fodder round the year & 62 & 31.00 \\
\hline 4. & Non-availability of grazing land & 42 & 21.00 \\
\hline 5. & Deficiency of balanced diet & 33 & 16.50 \\
\hline 6. & Non-availability of animal feed regularly & 23 & 11.5 \\
\hline C. & Management & & \\
\hline 1. & $\begin{array}{l}\text { Lack of knowledge about scientific methods of } \\
\text { milking }\end{array}$ & 156 & 78.00 \\
\hline 2. & High calf mortality rate & 35 & 17.50 \\
\hline 3. & $\begin{array}{l}\text { Negligence of care and management of pregnant and } \\
\text { new born calf due to lack of time. }\end{array}$ & 25 & 12.50 \\
\hline 4. & Non-availability of drinking water & 12 & 6.00 \\
\hline D. & Health & & \\
\hline 1. & Ticks and other ectoparasites present in animal shed & 192 & 96.00 \\
\hline 2. & Cross bred animals are more prone to diseases & 173 & 86.50 \\
\hline 3. & $\begin{array}{l}\text { Lack of knowledge about animal diseases and } \\
\text { vaccination }\end{array}$ & 130 & 65.00 \\
\hline 4. & $\begin{array}{l}\text { Non-availability of veterinary services and } \\
\text { medicines nearby area }\end{array}$ & 05 & 2.50 \\
\hline E. & Economic & & \\
\hline 1. & Non availability of capital and loan at proper time. & 22 & 11.00 \\
\hline 2. & Cost of cross breeds dairy animal is very high & 178 & 89.00 \\
\hline 3. & Vaccination is an expensive thing & 33 & 16.50 \\
\hline 4. & Construction of new shed is not cost effective & 32 & 16.00 \\
\hline 5. & Milk does not fetch well price in local market. & 16 & 8.00 \\
\hline 6. & High interest rates on loan & 10 & 5.00 \\
\hline 7. & Delayed Incentives from milk co-operatives & 04 & 2.00 \\
\hline 8. & The cost of veterinary treatment is more & 10 & 5.00 \\
\hline F. & Milk Distribution & & \\
\hline 1. & Milk production of local breeds is very low & 185 & 92.50 \\
\hline 2. & $\begin{array}{l}\text { No facility of training about diary farming at local } \\
\text { level or village level of member producers }\end{array}$ & 175 & 87.50 \\
\hline 3. & Lack of milk storage facility & 13 & 6.50 \\
\hline 4. & Non-availability of labours for milking & 09 & 4.50 \\
\hline 5. & Milk co-operatives do not collect milk within time & 05 & 2.50 \\
\hline
\end{tabular}


However, 16.5 and $11.5 \%$ of the respondents faced constraints of balanced diet for animals and timely non-availability of concentrates.

\section{Management}

Among the management relatedconstraints, $78.00 \%$ of the respondents reported lack of knowledge about scientific method of milking as a major constraint followed by $17.50 \%$ of the respondents had the constraint of calf mortality, whereas 12.50 and $6.00 \%$ of the respondents reported lack of time to adopt managemental practices of pregnant and new born calf and non-availability of clean drinking water, respectively.

\section{Health}

It was revealed that among the health constraints $96.00,86.50$ and $65.00 \%$ of the respondents reported tick and mosquito infestation, high susceptibility to disease in crossbreds and lack of knowledge about diseases and vaccination of dairy animals, respectively. However, only $2.5 \%$ respondents reported constraint of nonavailability of veterinary services and medicines in nearby area.

\section{Economical}

Regarding economical constraints, 94.00\% reported higher expenses over feed and fodder and high cost of crossbred dairy animals, respectively followed by $16.5,16.00$, and $11.00 \%$ of the respondents reported that vaccination is an expensive thing, new construction of new shed is not cost effective and non availability of capital and loan at proper time, respectively. However, 8.00, $5.00,5.00$ and $2 \%$ had constraint that milk does not fetch high price in local market, cost of veterinary treatment is more, high interest rates on loan, delayed incentives from milk co-operatives as a major constraints, respectively.

\section{Milk distribution}

The majority $(92.50 \%)$ of the respondents reported that low productivity of non-descript breeds of animals followed by $87.5 \%$ of respondents had constraint of lack of training centre for dairy business at local or village level, whereas 6.50 and $4.50 \%$ of the respondents reported non-availability of facilities for milk preservation and nonavailability of laboures for milking of animals respectively. However, 2.5 and $2.00 \%$ of the respondents had constraint of delay in milk collection by dairy co-operatives and only once a day collection of milk by the dairy cooperatives.

Present findings are in agreement with the findings of Thorat and Kulkarni (1994), Vyas and Patel (2000), Manoharan et al., (2003), Narendrareddy et al., (2003) and Singh et al. (2004) who have reported similar constraints perceived by dairy farmers in terms of dairy farming and clean milk production.

In conclusion ticks and other ectoparasites present in animal shed, milk production of local breeds is very low, dairy animals require large quantity of feed, higher cost of concentrate and cross bred animals are more prone to diseases were the major constraints encountered by the dairy farmers.

\section{References}

Manoharan, R., Selvakumar, K.N., Pandian, A.S.S. 2003. Constraints in milk production faced by the farmers in Pondicherry Union Territory. Indian J. Anim. Res., 37(1): 68-70.

Narendrareddy, P.V.R., Moorthy, P.R.S., Rao, S.K. 2003. Constraints in dairy farming in Prakasam district of Andhra Pradesh. Indian J. Extension Education, 39(1\&2): 69-73.

Rathod, P., Balraj, S., Dhanraj, G., Madhu, 
R., Chennaveerappa, Ajith, M.C. 2014. Knowledge level of dairy farmers about artificial insemination in Bidar district of Karnataka, India. Vet. Res. Int., 2(2): 46-50.

Singh, P.R., Singh, M., Jaiswal, R.S. 2004. Constraints and strategies in rural livestock farming in Almora district of Uttaranchal. Indian J. Anim. Res., 38(2):
91-96.

Thorat, D.R., Kulkarni, B.R. 1994. Constraints faced by dairy farmers. Maharashtra J. Extn. Edu., 13: 305306.

Vyas, H.U., Patel, K.F. 2000. Constraints faced by milk producers in adoption of dairy technology. Agri. Extension Rev., 12: $23-25$.

\section{How to cite this article:}

Panchbhai, G.J., M.F. Siddiqui, M.N. Sawant, A.P. Verma and Parmeswaranaik, J. 2017. Constraints Faced by Co-Operative Dairy Farmers in Adoption of Recommended Dairy Management Practices. Int.J.Curr.Microbiol.App.Sci. 6(3): 1962-1966. doi: https://doi.org/10.20546/ijcmas.2017.603.223 